сурсы и природопользование: сб. науч. трудов. Сургут: Дефис, 2008. Вып. 11. С. 173-181.

30. Федоров В.Г. Позвоночные животные-хозяева клеща Ixodes trianguliceps Bir. в Западной Сибири // Современный мир, природа и человек: сб. науч. тр. Томск: ТГУ, 2009. С. 40-41.

31. Стариков В.П., Винарская Н.П., Берников К.А. Эпизоотологическая ситуация по туляремии в Среднем Приобье (в фазу депрессии численности водяной полевки) // Популяционная экология животных: II междунар. науч. конф., посв. памяти академика И.А. Шилова (Томск, 10-14 октября 2016 г.). Принципы экологии. 2016. Т. 5, № 3 (19). С. 146.

32. Петров В.Г., Олсуфьев Н.Г. О размножении Bacterium tularense в клещах Dermacentor pictus Herm. в процессе метаморфоза // Вопросы краевой, общей и экспериментальной паразитологии и медицинской зоологии. 1953. Т. 8. С. 149-156.

33. Ершова Л.С. Клещи Ornithodoros lahorensis и Ornithodoros papillipes как хранители и переносчика туляремийного микроба (в эксперименте): автореф. дис. .... канд. биол. наук. Алма-Ата, 1964. 21 с.

34. Петров В.Г. О трансовариальной передаче возбудителя туляремии у клещей Dermacentor marginatus Sulz. // Мед. паразитол. 1962. № 1. С. 62-66.

35. Олсуфьев Н.Г. Таксономия, микробиология и лабораторная диагностика возбудителя туляремии. М.: «Медицина», 1975. 192 с.

36. Балашов Ю.С. Иксодовые клещи - паразиты и переносчики инфекций. СПб.: Наука, 1998. 287 с.

\title{
MATERIALS ON IXODES TICK (IXODIDAE) OF THE KHANTY-MANSI AUTONOMOUS OKRUG - YUGRA
}

Starikov Vladimir Pavlovich, doctor of biological sciences, professor, chief researcher of the North Ecology Research Institute

Surgut State University (Surgut, Khanty-Mansi Autonomous Okrug - Yugra, Russian Federation)

Mayorova Antonina Dmitrievna, candidate of biological sciences, associate professor of Botany and Zoology Department Ivanovo State University (Ivanovo, Russian Federation)

Sarapultseva Ekaterina Sergeevna, student of Natural and Technical Sciences Institute

Bernikov Kirill Alexandrovich, candidate of biological sciences, associate professor of Biology and Biotechnology Department

Nakonechny Nikolay Vladimirovich, candidate of biological sciences, senior researcher of the North Ecology Research Institute

Morozkina Anna Vladimirovna, candidate of biological sciences, lecturer of Biology and Biotechnology Department

Borodin Andrey Vladimirovich, postgraduate student of Biology and Biotechnology Department

Petukhov Vladimir Aleksandrovich, postgraduate student of Biology and Biotechnology Department Surgut State University (Surgut, Khanty-Mansi Autonomous Okrug - Yugra, Russian Federation)

Abstract. The paper contains information about ixodid mites of the Khanty-Mansi Autonomous Okrug - Yugra, obtained during expedition work in 2006-2016. Ixodes persulcatus dominates in the structure of the population of ixodid ticks. The list of small mammals serving as feeders of ixodid ticks is indicated. The highest indices of occurrence and abundance of ixodid ticks were introduced for Myodes rutilus and Craseomys rufocanus (28,6 and 25,0\%, 0,8 and 0,9 respectively). Researches in Nizhnevartovsk region in 2016 confirmed the opinion about total absence of ixodid mites on flooded part of the floodplain because of usual overflows. All ixodid ticks are registered in rodents and shrews on mainland part. The same feature in location of ixodid matis in 2013 was observed in surroundings of Khanty-Mansiysk city. The paper contains the information about distribution of ixodid ticks on feeders in Nizhnevartovsk region.

Keywords: ectoparasites; Ixodid mites; Ixodes persulcatus; Ixodes apronophorus; Ixodes trianguliceps; Ixodes vespertilionis; Tyumen Region; Khanty-Mansi Autonomous Okrug - Yugra; small mammals; insectivorous; bats; rodents; feeders of ixodid ticks; abundance and occurrence indices.

УДК 550.47:504.054:582.272

\section{ОЦЕНКА ЭКОЛОГИЧЕСКОГО СОСТОЯНИЯ ЗАЛИВА ПОСЬЕТА (ЯПОНСКОЕ МОРЕ) ПО СОДЕРЖАНИЮ ТЯЖЕЛЫХ МЕТАЛЛОВ В БУРЫХ ВОДОРОСЛЯХ-МАКРОФИТАХ}

(C) 2017

Христофорова Надежда Константиновна, доктор биологических наук, профессор, заведующий кафедрой ЮНЕСКО «Морская экология»; ведущий научный сотрудник лаборатории геохимии Дальневосточный федеральный университет; Тихоокеанский институт географии ДВО РАН

(2. Владивосток, Российская Федерация)

Кобзарь Анна Дмитриевна, старший преподаватель кафедры экологии Дальневосточный федеральный университет (2. Владивосток, Российская Федерация)

Аннотация. Изучено содержание тяжелых металлов в двух видах саргассумов (Sargassum miyabei, Sargassum pallidum), а также цистозире толстоногой (C. crassipes) в прибрежных водах залива Посьета. Анализ пространственного распределения микроэлементов выявил наибольшее содержание цинка, меди и никеля в бух- 
те Троицы, обусловленное рекреационным прессом, и повышенные концентрации никеля и кадмия в бухте Сивучьей, вызванные, очевидно, трансграничным атмосферным переносом. Установлено, что все выявленные концентрации элементов превышают фоновые природные значения для северо-западной части Японского моря. Показано, что по сравнению с 1998 г. произошло явное изменение экологической ситуации в заливе: резко снизилась концентрация свинца $(\mathrm{p}=0,013)$, что, по-видимому, является отражением общемировой ситуации, обусловленной прекращением использования тетраэтилсвинцовой добавки в качестве антидетонатора к бензиновому топливу; уменьшилось содержание цинка $(p=0,05)$, меди $(p=0,02)$ и кадмия $(p=0,012)$, что может быть связано со снижением влияния со стороны свободной экономической зоны, расположенной на китайской стороне на р. Туманной. В выбранной для сравнения бухте северного Приморья, относящейся к Сихотэ-Алинскому заповеднику, концентрации всех элементов полиметаллической группы выше, что вызвано геохимическими условиями - свинцово-цинковой специализацией горнорудного района.

Ключевые слова: тяжелые металлы; поллютанты; залив Посьета; Дальневосточный государственный морской заповедник; Японское море; региональный фоновый уровень; бурые водоросли; Sargassum meyabei; Sargassum pallidum; Cystoseira crassipes; экологический мониторинг; биоиндикация.

\section{Введение}

Залив Посьета является заливом второго порядка, относящимся к акватории зал. Петра Великого. На берегу залива располагается несколько небольших населенных пунктов: поселки Зарубино, Посьет и Краскино, село Андреевка и целый ряд мелких поселений. В настоящее время на побережье залива размещается множество баз отдыха и активно развивается туризм.

В зал. Посьета находятся несколько крупных международных портов: ОАО «Торговый порт Посьет», обеспечивающий поставки угля в страны азиатскотихоокеанского региона; порт Зарубино, являющийся важным звеном Российского международного транспортного коридора «Приморье - 2»; ОАО «Морской порт в б. Троицы», на территории которого осуществляется рыбообработка, перегрузка автотранспорта, лесных и опасных грузов, имеется рефрижераторный комплекс.

Часть акватории залива относится к Дальневосточному морскому биосферному государственному природному заповеднику (ДВГМЗ) - к южному и западному его участкам. В пределах южного участка допускается по особому разрешению дирекции ДВГМЗ фото- и видеосъемка, проведение научных исследований, связанных с разработкой основ сохранения и восстановления морских сообществ, мониторингом и инвентаризацией морского населения заповедника. На самом маленьком участке - Западном (камни Сивучьи, бухты Миноносок и Крейсерок), наряду с сохранением естественных сообществ, отрабатываются биологические основы марикультуры - АО «Темп» по соглашению с ДВГМЗ выращивает молодь приморского гребешка для пополнения и восстановления естественных популяций в заповеднике и для марикультурных хозяйств Приморского края.

Со времен проекта TREDA (Tumen River Economic Development Area), связанного с экономическим развитием территории пограничной реки Туманной и трансграничным переносом тяжелых металлов и других поллютантов, реализовавшегося в конце 1990-х гг. [1-4], экологических исследований в заливе Посьета, в частности, в акваториях морского заповедника, не проводилось. В связи с этим важно было провести обследование залива для получения представления о его современном состоянии.

\section{Объекты и методы исследования}

Данная работа посвящена исследованию загрязнения прибрежно-морских вод такими металлами, как железо, цинк, медь, кадмий, никель, свинец.
Первый из них характеризует преимущественно терригенный сток, два вторых, если они не связаны с добычей и переработкой руд, выплавкой металлов и гальваническими цехами, - коммунально-бытовое воздействие (оба входят в число тривиальных компонентов хозяйственно-бытовых стоков). Три последних являются трассерами техногенного пресса на окружающую среду [5, с. 10-18].

Определение загрязнения прибрежных вод тяжелыми металлами проведено с применением аккумулирующих организмов-индикаторов - бурых водорослей Sargassum miyabei, Sargassum pallidum и Cystoseira crassipes. Биоиндикация с использованием бурых водорослей-макрофитов получила широкое распространение с начала 1970-х гг. [6-9] и продолжает применяться для оценки качества среды в настоящее время [10-20].

Нами использованы два вида саргассов, обитающих в зал. Петра Великого, - Sargassum miyabei, Sargassum pallidum. Согласно Е.М. Крепсу [21], контроль условий среды следует производить, сравнивая систематически близкие виды. Вот почему мы считаем правомерным сравнение двух видов водорослей рода Sargassum.

Пробы водорослей отбирали в заливе Посьета на 7 станциях (рис. 1) в июле 2016 г. С каждой станции брали по 3 слоевища макрофитов. При обработке водорослей, подготовке проб к анализу и атомноабсорбционном анализе на спектрофотометрах Shimadzu AA-6800 использовали известные подходы и приемы [5, с. 56-58]. Точность определения концентрации всех металлов контролировали, анализируя стандартные образцы (NIES 9.0 «Sargasso»). Ошибка определения не превышала 15\%. Концентрацию металлов выражали в мкг/г сух. массы.

Расчет среднего и стандартного отклонения осуществляли в программе Excel. Для выявления межгодовых изменений в накоплении металлов бурыми водорослями, а также сравнения изучаемых акваторий с другими бухтами и заливами побережья Приморского края использовали опубликованные и полученные ранее данные [4; 11]. Достоверность различий определяли с использованием U-теста по методу Манна-Уитни в программе SPSS Statistics.

\section{Результаты исследования и их обсуждение}

Результаты анализа микроэлементного состава макрофитов залива Посьета приведены в табл. 1.

В этом объемном фактурном материале целесообразно начать анализ результатов с пространственного распределения содержания тяжелых металлов в водорослях на станциях в заливе Посьета. 


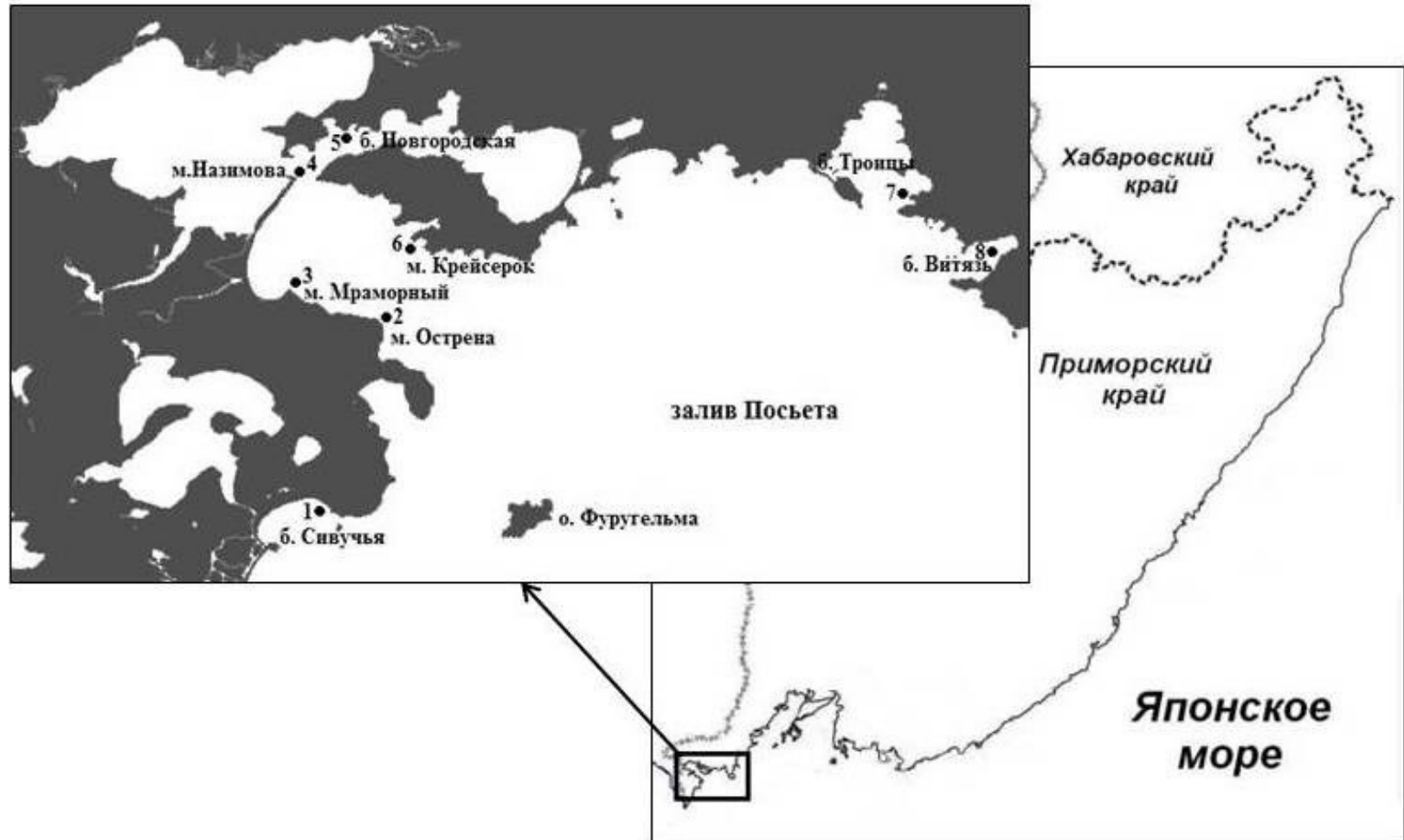

Рисунок 1 - Станции отбора проб водорослей в зал. Посьета: 1 - б. Сивучья, 2 - м. Острена, 3 - м. Мраморный, 4 - м. Назимова, 5 - б. Новгородская, 6 - м. Крейсерок, 7 - 6. Троицы, 8 - 6. Витязь

таблица 1 - Среднее содержание тяжелых металлов (мкг/г) в талломах бурых водорослей, собранных в

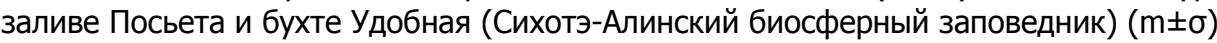

\begin{tabular}{|c|c|c|c|c|c|c|c|c|}
\hline Станция & $\begin{array}{c}\text { Год } \\
\text { отбора }\end{array}$ & $\begin{array}{c}\text { Вид } \\
\text { водоросли }\end{array}$ & $\mathrm{Fe}$ & $\mathrm{Zn}$ & $\mathrm{Cu}$ & $\mathrm{Cd}$ & $\mathrm{Ni}$ & $\mathrm{Pb}$ \\
\hline \multicolumn{9}{|c|}{ Юго-западная часть залива Петра Великого } \\
\hline \multirow{2}{*}{ Б. Сивучья } & 1998 & \multirow{2}{*}{ S. pallidum } & $233 \pm 19$ & $20,0 \pm 1,7$ & $4,20 \pm 1,02$ & $3,60 \pm 0,04$ & $6,02 \pm 0,30$ & $12,50 \pm 2,10$ \\
\hline & 2016 & & $186 \pm 2$ & $14,9 \pm 0,2$ & $2,01 \pm 0,17$ & $2,89 \pm 0,03$ & $6,27 \pm 0,13$ & $1,09 \pm 0,06$ \\
\hline М. Острена & 2016 & C. crassipes & $103 \pm 17$ & $29,6 \pm 0,3$ & $2,88 \pm 0,04$ & $3,66 \pm 0,19$ & $4,69 \pm 0,04$ & $2,89 \pm 0,22$ \\
\hline \multirow{2}{*}{ М. Мраморный } & 1998 & \multirow{2}{*}{ S. miyabei } & $370 \pm 146$ & $17,0 \pm 1,1$ & $2,97 \pm 0,14$ & $3,90 \pm 0,16$ & $5,70 \pm 0,20$ & $23,10 \pm 6,50$ \\
\hline & 2016 & & $141 \pm 7$ & $9,93 \pm 0,11$ & $1,42 \pm 0,14$ & $2,74 \pm 0,03$ & $5,04 \pm 0,09$ & $0,64 \pm 0,04$ \\
\hline М. Назимова & 2016 & S. pallidum & $389 \pm 9$ & $12,02 \pm 0,05$ & $2,19 \pm 0,23$ & $2,48 \pm 0,01$ & $5,55 \pm 0,21$ & $1,12 \pm 0,01$ \\
\hline \multirow{3}{*}{$\begin{array}{l}\text { Б. Новгород- } \\
\text { ская }\end{array}$} & 2016 & S. miyabei & $231 \pm 15$ & $13,76 \pm 0,18$ & $2,16 \pm 0,07$ & $2,92 \pm 0,13$ & $6,67 \pm 0,42$ & $0,93 \pm 0,04$ \\
\hline & 1998 & \multirow{2}{*}{ S. pallidum } & $748 \pm 499$ & $14,0 \pm 4,5$ & $3,70 \pm 1,40$ & $3,20 \pm 0,50$ & $6,30 \pm 1,80$ & $11,20 \pm 2,40$ \\
\hline & 2016 & & $121 \pm 4$ & $6,70 \pm 0,19$ & $2,95 \pm 0,03$ & $1,95 \pm 0,01$ & $4,30 \pm 0,10$ & $0,63 \pm 0,10$ \\
\hline М. Крейсерок & 2016 & S. miyabei & $95 \pm 23$ & $12,65 \pm 0,29$ & $1,82 \pm 0,08$ & $2,38 \pm 0,01$ & $5,11 \pm 0,03$ & $1,56 \pm 0,16$ \\
\hline Б. Троицы & 2016 & S. miyabei & $54 \pm 4$ & $16,47 \pm 0,32$ & $2,44 \pm 0,09$ & $3,17 \pm 0,01$ & $5,27 \pm 0,20$ & $0,91 \pm 0,14$ \\
\hline Б. Витязь & 2016 & S.pallidum & $386 \pm 4$ & $9,58 \pm 0,25$ & $1,93 \pm 0,14$ & $1,86 \pm 0,03$ & $5,41 \pm 0,02$ & $1,74 \pm 0,03$ \\
\hline \multicolumn{9}{|c|}{ Б. Удобная (САБЗ) } \\
\hline Южный мыс & 2010 & C. crassipes & $212 \pm 19$ & $45,1 \pm 3,1$ & $1,73 \pm 0,16$ & $3,32 \pm 0,24$ & $1,05 \pm 0,22$ & $4,55 \pm 0,09$ \\
\hline \multicolumn{9}{|c|}{ Фон (по [20]) } \\
\hline & & C. crassipes & $37 \pm 8$ & $15,9 \pm 0,9$ & $1,3 \pm 0,4$ & $1,5 \pm 0,1$ & $1,6 \pm 0,3$ & - \\
\hline & & S. miyabei & $116 \pm 37$ & $10,7 \pm 1,8$ & $1,5 \pm 0,2$ & $0,8 \pm 0,1$ & $1,2 \pm 0,4$ & $0,3 \pm 0,4$ \\
\hline & & S. pallidum & $92 \pm 31$ & $7,1 \pm 0,9$ & $1,1 \pm 0,2$ & $0,6 \pm 0,1$ & $0,6 \pm 0,2$ & $0,3 \pm 0,4$ \\
\hline
\end{tabular}

Как типичный терригенный элемент Fе поступает в морскую среду преимущественно за счет поверхностного смыва, речного стока, мобилизации в раствор из донных осадков на мелководье, взмучивания и биотурбации донных отложений $[5$, с. $68-76 ; 22$, c. 94-104]. Наименьшему терригенному стоку подвержены водоросли, собранные у скалистого мыса на юго-востоке б. Троицы (54 мкг/г), что и понятно, поскольку здесь практически нет источников его выноса. В то же время в районе м. Назимова и б. Витязь выявлено наибольшее содержание элемента в саргассах (389 и 386 мкг/г соответственно), что обусловле- но высокой мутностью и динамикой вод в мелководной и заиленной б. Экспедиции у м. Назимова и мягкими грунтами в месте сбора в б. Витязь.

Изменчивость концентраций цинка в макрофитах из разных мест сбора была небольшой: разница между наибольшим и наименьшим значением составляла 2,5 раза. Повышенное содержание $\mathrm{Zn}$ определено в б. Троицы (16,47 мкг/г). Для макрофитов данной станции характерно и довольно высокое содержание меди $(2,44$ мкг/г), что, очевидно, вызвано обилием отдыхающих, располагающихся в палатках и на базах отдыха по всему периметру этой бухты. 
Среди техногенных металлов актуальность свинца после прекращения использования тетраэтилсвинцовой добавки к бензину в качестве антидетонатора существенно снизилась. Об этом свидетельствуют и данные, полученные нами ранее [19]. Для сборов 2016 г. характерны очень низкие значения концентраций данного элемента в водорослях - 0,631,74 мкг/г. В то же время никель и кадмий не утратили своей «привлекательности» как поллютанты. Несмотря на небольшие различия между значениями концентраций $\mathrm{Ni}$, этот элемент явно преобладал в макрофитах на двух станциях: в б. Новгородской $(6,67$ мкг/г) и б. Сивучьей $(6,27$ мкг/г). На этих же станциях отмечалось повышенное содержание $\mathrm{Cd}$, хотя наиболее высокие его концентрации выявлены у м. Острена и в б. Троицы. Кажущееся невероятным повышенное содержание обоих металлов в б. Сивучьей (ДВГМЗ) обусловлено, по-видимому, трансграничным атмосферным переносом от промышленно развитых «соседей» - Китая и Кореи, что было замечено и в более ранние годы [4]. Большое количество кадмия в макрофитах б. Троицы, несомненно, связано с рекреационной нагрузкой, что было отмечено для цинка и меди.

Среди заповедных территорий к морскому побережью выходит Сихотэ-Алинский биосферный заповедник (б. Удобная). В ней был собран третий вид исследуемых нами водорослей - C.crassipes. Как следует из данных табл. 1, за исключением меди и никеля, содержание всех металлов в цистозире б. Удобной выше, чем в макрофитах, собранных у м. Острена. Северное Приморье отличается от Южного геохимическими условиями: более высокими концентрациями цинка, свинца и кадмия, которые являются компонентами свинцово-цинковых полиметаллических руд, разрабатываемых в горнорудном районе на севере края. Очевидно, поэтому эти металлы проявляются в более высоких концентрациях в цистозирах б. Удобной. Никель сопровождает любые нефтепродукты и обнаруживается в среде и организмах, как в районах интенсивного судоходства и стоянки судов, так и при сжигании топлива [23, с. 175181] счет атмосферного переноса. Повышенная концентрация никеля в водорослях у м. Острена связана, по-видимому, с близким его расположением к рекомендованному курсу всех судов, идущих в порт Посьет, оставляющих свой след в водной среде.

Несмотря на принадлежность большинства обследованных станций к морскому заповеднику и отсутствие промышленных предприятий по всему побережью залива Посьета, за исключением порта Посьет, нами установлено, что в целом концентрации всех определяемых элементов оказались выше фоновых значений содержания металлов в бурых водорослях для северо-западной части Японского моря [20].

Межгодовые наблюдения позволяют выявить тенденции в изменении качества среды. Приведенные в таблице данные для 1998 и 2016 гг. свидетельствуют о резком снижении концентрации свинца $(\mathrm{p}=0,013)$ в среде и организмах, что было замечено нами и для Амурского залива [19]. Значительно уменьшилось содержание цинка $(\mathrm{p}=0,05)$ - в 1,3 2,1 раза и меди $(\mathrm{p}=0,02)$ - в $1,2-2,1$ раза. Несколько понизился также уровень кадмия $(\mathrm{p}=0,012)$ - в 1,2
1,6 раза. Это может быть обусловлено уменьшением пресса со стороны свободной экономической зоны, созданной на реке Туманная (Туманган) в Китае. И лишь концентрации никеля практически не изменились.

Таким образом, по сравнению с концом 1990-х годов произошло явное изменение экологической ситуации в заливе в сторону улучшения: резко снизилась концентрация свинца, что, по-видимому, является отражением общемировой ситуации, обусловленной прекращением использования тетраэтилсвинцовой добавки в качестве антидетонатора к бензиновому топливу; уменьшилось содержание цинка, меди и кадмия, что может быть связано со снижением трансграничного переноса тяжелых металлов с китайской стороны.

\section{СПИСОК ЛИТЕРАТУРЫ:}

1. Вышкварцев Д.И., Лебедев Е.Б. Проект экономического развития реки Туманган (TREDA) - угроза экосистеме мелководных бухт залива Посьета Японского моря // Биология моря. 1997. Т. 23, № 1. C. 51-55.

2. Мощенко А.В., Ванин Н.С., Ламыкина А.Е. Рельеф дна, донных отложений и гидрологические условия российской части приустьевой зоны реки Туманной // Экологическое состояние и биота югозападной части залива Петра Великого и устья реки Туманной. Владивосток: Дальнаука, 2000. Т. 1. C. $42-75$.

3. Шулькин В.М. Оценка загрязнения металлами вод реки Туманной и прилегающих морских вод // Экологическое состояние и биота юго-западной части залива Петра Великого и устья реки Туманной. Владивосток: Дальнаука, 2000. Т. 1. С. 76-85.

4. Коженкова С.И., Христофорова Н.К. Биомониторинг содержания тяжелых металлов в морских прибрежных водах юго-западной части залива Петра Великого с использованием бурых водорослей // Экологическое состояние и биота юго-западной части залива Петра Великого и устья реки Туманной. Т. 3. Владивосток: Дальнаука, 2002. С. 33-41.

5. Христофорова Н.К. Биоиндикация и мониторинг загрязнения морских вод тяжелыми металлами. Л.: Наука, 1989. 192 с.

6. Bryan G.V., Hummerstone L.G. Brown seaweed as indicator of heavy metals in estuaries in south-west England // J. Mar. Biol. Ass. U. K. 1973. Vol. 53. P. 705-720.

7. Fuge R., James K. Trace metal concentration in Fucus from the Bristol Channel // Mar. Pollut. Bull. 1974. Vol. 5, № 1. P. 9-12.

8. Fowler S.W. Use of macroalgae as a reference material for pollutant monitoring and specimen banking // Monitoring environmental materials and specimen banking: Proc. Int. Workshop. Berlin. 1978. London. 1979. P. 247-260.

9. Bryan G.V. Recent trends in research on heavymetal contamination in the sea // Helgalander Meeresunters. 1980. Vol. 33. P. 6-25.

10. Khristophorova N.K., Kozhenkova S.I. The use of the brown algae Sargassum spp. in heavy metal monitoring of marine Environment near Vladivostok, Russia // Ocean Polar Res. 2002. Vol. 24, № 4. P. 325-329. 
11. Чернова Е.Н., Христофорова Н.К., Вышкварцев Д.И. Тяжелые металлы в морских травах и водорослях залива Посьета Японского моря // Биология моря. 2002. Т. 28, № 6. С. 425-430.

12. Strezov A., Nonova T. Monitoring of $\mathrm{Fe}, \mathrm{Mn}, \mathrm{Cu}$, $\mathrm{Pb}$ and $\mathrm{Cd}$ levels in two brown macroalgae from the Bulgarian Black Sea coast // Environmental Analitical Chemistry. 2003. Vol. 83, No. 12. P. 1045-1054.

13. Hedouin L., Bustamante P., Fichez R., Warnau M. The tropical brown alga Lobophora variegate as bioindicator of mining contamination in the New Caledonia lagoon: A field transplantation study // Marine Environmental Research. 2008. No. 66. P. 438-444.

14. Akcali I., Kucuksezgin F. A Biomonitoring stady: Heavy metals in macroalgae from Eastern Aegean coastal areas // Marine Poll. Bullet. 2011. Vol. 62. P. 637-645.

15. Brito G.B., Souza Th.L., Bressy F.C., Moura C.W.N., Korn M. A. Levels and spatial distribution of trace elements in macroalgae species from the Todos os Santos Bay, Bahia, Brazil // Marine Pollution Bulletin. 2012. No. 64. P. 2238-2244.

16. Христофорова Н.К., Кобзарь А.Д. Бурые водоросли-макрофиты как индикаторы загрязнения вод бухты Рудной тяжелыми металлами // Известия ТИНРО. 2012. Т. 168. С. 220-231.

17. Шулькин В.М., Чернова Е.Н., Х Христофорова Н.К., Коженкова С.И. Влияние горнорудной деятельности на изменение химического состава компонентов водных экосистем // Геоэкология. Инженер- ная геология. Гидрогеология. Геокриология. 2014. № 6. С. 483-494.

18. Христофорова Н.К., Гамаюнова О.А., Афанасьев А.П. Состояние бухт Козьмина и Врангеля (залив Петра Великого, Японское море): динамика загрязнения тяжелыми металлами // Известия ТИНРО. 2015. Т. 180. С. 179-186.

19. Кобзарь А.Д., Христофорова Н.К. Мониторинг загрязнения прибрежных вод Амурского залива (Японское море) тяжелыми металлами с использованием бурой водоросли Sargassum miyabei Yendo, 1907 // Биология моря. 2015. Т. 41, № 5. С. 361-365.

20. Чернова Е.Н., Коженкова С.И. Определение пороговых концентраций металлов в водоросляхиндикаторах прибрежных вод северо-западной части Японского моря // Океанология. 2016. Т. 56, № 3. C. 393-402.

21. Крепс Е.М. Об оценке сравнительно-физиологических факторов // I Совещ. Биогруппы АН СССР по физиологическим проблемам. М., Л.: Издво АН СССР, 1937. С. 31-32.

22. Шулькин В.М. Металлы в экосистемах морских мелководий. Владивосток: Дальнаука, 2004. $279 \mathrm{c}$.

23. Мур Дж.В., Рамамурти С. Тяжелые металлы в природных водах: Контроль и оценка влияния. М.: Мир, 1987.288 c.

Работа выполнена при финансовой поддержке Российского научного фонда (соглащение № 14-5000034).

\section{ASSESSMENT OF ECOLOGICAL STATE OF THE POSYET BAY (THE SEA OF JAPAN) BY HEAVY METALS CONTENT IN BROWN ALGAE}

(C) 2017

Khristoforova Nadezhda Konstantinovna, doctor of biological sciences, professor, head of Marine Ecology UNESCO Department; leading researcher of Geochemistry Laboratory

Far Eastern Federal University; Pacific Institute of Geography of Far East Branch of Russian Academy of Sciences (Vladivostok, Russian Federation

Kobzar Anna Dmitrievna, senior lecturer of Ecology Department Far Eastern Federal University (Vladivostok, Russian Federation)

Abstract. The paper contains the study of heavy metals in three species - Sargassum miyabei, Sargassum pallidum, Cystoseira crassipes in the coastal waters of the Posyet Bay. The analysis of the spatial distribution of trace elements revealed the highest contents of zinc, copper and nickel in the Troitsa Bight, due to recreational pressure and a high concentration of nickel and cadmium in Sivuchya Bight that was caused by transboundary atmospheric transport. All of detected concentrations exceed natural background values for the North-Western part of the Sea of Japan. The authors show that there has been a distinct change in the environmental situation in the the Posyet Bay since 1998: the concentration of lead has sharply decreased, the content of zinc, copper and cadmium has decreased, it could be connected with influence reduction in the free economic zone, located on the Chinese side on the Tumannaya River.

Keywords: heavy metals; pollutants; Posyet Bay; Far East Marine State Reserve; Sea of Japan; regional background levels; brown algae; Sargassum meyabei; Sargassum pallidum; Cystoseira crassipes; environmental monitoring; bioindication. 